\title{
Use of casein micelles to improve the solubility of hydrophobic pea proteins in aqueous solutions via low-temperature homogenization
}

\author{
Abigail Krentz, Israel García-Cano, Joana Ortega-Anaya, and Rafael Jiménez-Flores*
}

Department of Food Science and Technology, The Ohio State University, Parker Food Science and Technology Building, Columbus 43210

\begin{abstract}
The dairy industry struggles to maintain consumer attention in the midst of declining fluid milk sales. Current trends create an opportunity to incorporate plantbased proteins with milk to produce a high-protein, multisourced, functional food product. Plant-based proteins, such as those in peas, can be challenging to use in food systems because of their low solubility and undesirable off-flavors. Casein micelles have unique structural properties that allow for interactions with small ions and larger macromolecules that aid in their noteworthy ability as a nanovehicle for hydrophobic compounds. The objective of this study was to use the inherent structure of the casein micelle along with common dairy processing equipment to create a stable colloidal dispersion of casein micelles with pea protein to improve its solubility in aqueous solutions. We created 3 blends with varying ratios of casein-to-pea protein (90:10, 80:20, 50:50). We subjected the mixtures to 3 cycles of homogenization using a bench-top GEA 2-stage homogenizer at $27,580 \mathrm{kPa}$ maintained at $4^{\circ} \mathrm{C}$, followed by pasteurization at $63^{\circ} \mathrm{C}$ for $30 \mathrm{~min}$. The resulting blends were homogeneous liquids with increased stability due to the lack of protein precipitation. Further protein analysis by HPLC and AA sequencing revealed that vicilin, an insoluble storage protein, was the main pea protein incorporated within the casein micelle structure. These results supported our hypothesis that low-temperature homogenization can successfully be used to create a colloidal dispersion with increased stability, in which insoluble plant-based proteins may be incorporated with casein micelles in an aqueous solution. Additionally, 3-dimensional microscope images of the blends indicated a noticeable difference between the surface roughness upon addition of pea protein to the casein micelle matrix. This research highlights a promising application for other plant-based proteins to be used within the dairy industry to help drive future
\end{abstract}

Received June 21, 2021.

Accepted August 30, 2021.

*Corresponding author: jimenez-flores.1@osu.edu product innovation while also meeting current processing conditions and consumer demands.

Key words: casein micelle, pea protein, homogenization, colloidal dispersion

\section{INTRODUCTION}

Caseins account for $80 \%$ of the total proteins in milk and self-assemble into casein micelles $(\mathbf{C M})$. The CM contain the 4 major $\mathrm{CN}$ subgroups $\left(\alpha_{\mathrm{S} 1}, \alpha_{\mathrm{S} 2}, \beta, \kappa\right)$ along with colloidal calcium phosphate, held together by noncovalent interactions including electrostatic, hydrophobic, and hydrogen bonding (Holt and Horne, 1996; Horne, 1998; Walstra, 1999). The structure of CM can be disrupted by the addition of chelating agents, $\mathrm{NaCl}$, and cations. Additionally, changes in the solution temperature and $\mathrm{pH}$ can also disrupt the micelle structure. For example, calcium phosphate exhibits greater solubility at lower temperatures, and thus is released from the micelle upon cooling to $4^{\circ} \mathrm{C}$ (Koutina et al., 2014). Similarly, hydrophobic $\beta-\mathrm{CN}$ is also released from the micelle at lower temperatures (Pierre and Brule, 1981; Liu et al., 2013). The release of colloidal calcium phosphate and $\beta-\mathrm{CN}$ creates a looser, dissociated micelle structure. The same effect is observed upon the addition of chelating agents, such as sodium citrate. Upon the addition of sodium citrate $0.02 \mathrm{M}$, the resulting $\mathrm{CM}$ structure is larger in size due to the complexing of sodium citrate to calcium phosphate, ultimately leading to the release of $\beta$-CN (Heertje et al., 1985).

The unique structure and hydrophobic core of $\mathrm{CM}$ allows them to serve as carriers of essential nutrients native to $\mathrm{CM}$, such as calcium, phosphate, and protein, along with the potential to serve as encapsulation vehicles for hydrophobic compounds. In general, encapsulation is carried out by first disassociating the $\mathrm{CM}$, then facilitating interactions between the hydrophobic compounds and the hydrophobic CN regions, and finally reassembling the CM structure (Głąb and Boratyński, 2017). For example, vitamin $\mathrm{D}_{2}$ and $\mathrm{D}_{3}$ have been incorporated within CM via ultra-high-pressure homogenization and restoration of mineral content to enrich low-fat foods (Menéndez-Aguirre et al., 2011; 
Menéndez-Aguirre et al., 2014; Cohen et al., 2017). Additionally, soybean oil, fish oil, and rapeseed oil have been successfully encapsulated within the hydrophobic regions of $\mathrm{CM}$ through $\mathrm{pH}$ shifts and ultrasound treatments (Ghasemi and Abbasi, 2014).

The aim of the presented research was to use CM to encapsulate another type of hydrophobic compound, plant-based protein. The demand for plant-based protein is growing due to consumers' desires for highprotein health benefits and environmentally conscious products (Boland et al., 2013). Pea protein (PP), chosen as the plant-based protein for this study, has become fairly popular due to its balanced AA composition and branched chain AA that assist in muscle synthesis and expansion (Babault et al., 2015). Pea protein is a nonallergenic, gluten-free, and cost-effective plant protein. However, it can be a challenge to use in food systems because of its low solubility and undesirable bitterness. Pea protein has a high percentage of hydrophobic proteins (65-80\%), making it a good hydrophobic model to represent plant-based proteins (Nehete et al., 2013; Lu et al., 2020). Other highly hydrophobic plant-based proteins such as soy, wheat, corn, and sunflower have potential to be applied in a $\mathrm{CM}$ encapsulation system (Nehete et al., 2013).

The objective of this study was to create a stable colloidal dispersion of $\mathrm{CM}$ with $\mathrm{PP}$ to improve the solubility of PP in aqueous solution. We hypothesized that low-temperature homogenization could be applied to an unstable dispersion of disrupted $\mathrm{CM}$ and $\mathrm{PP}$, and the resulting blend would be a stable colloidal dispersion in which the insoluble $\mathrm{PP}$ associate with $\mathrm{CM}$ in suspension. Unlike previous research studies, this protocol used readily available dairy processing equipment that could be easily reproduced in any dairy facility. This research highlighted a promising application for other plant-based proteins to be used within the dairy industry to help drive future product innovation.

\section{MATERIALS AND METHODS}

\section{Sample Preparation}

Commercial fat-free milk (Dean Foods Company) was purchased at local grocery stores. The skim milk sample was prepared by first dissociating the CM with $5.16 \mathrm{~g} / \mathrm{L}$ food-grade trisodium citrate (It's Just!, 138 Foods Inc.; Heertje et al., 1985). The skim milk was equilibrated at $4^{\circ} \mathrm{C}$ for $24 \mathrm{~h}$. The commercial skim milk used for this study had a nutrition label claiming $3.3 \%$ protein, of which $2.6 \%$ represented CM (Linn, 1988). For this reason, a PP slurry with $2.6 \%$ protein was developed to have a 1:1 protein ratio between the $\mathrm{CN}$ in the milk sample and the protein in the PP slurry. The $2.6 \%$ PP slurry was created by combining PP isolate (Mettle Nutrition LLC) with distilled water and continuous agitation at $25^{\circ} \mathrm{C}$ for $24 \mathrm{~h}$. The milk sample and the PP slurry were combined at different ratios of CM:PP (90:10, 80:20, and 50:50). We wanted the major protein component to be contributed by the CM; therefore, we did not create blends with less than 50\% CM. The skim milk with trisodium citrate and the $2.6 \% \mathrm{PP}$ slurry were the control samples used in this study to understand how each protein component behaved on its own.

\section{Homogenization and Pasteurization of CM:PP Blends}

Each protein blend underwent 3 cycles of lowtemperature $\left(4^{\circ} \mathrm{C}\right)$ homogenization using a bench-top GEA 2-stage homogenizer (NS2002 H, GEA Niro Soavi S.p.A.) at $24,130 \mathrm{kPa}$ (first stage) and 3,447 kPa (second stage). After homogenization, they were batch pasteurized in a water bath at $63^{\circ} \mathrm{C}$ and held for 30 min. The sample blends were stored at $-20^{\circ} \mathrm{C}$ until further analysis.

\section{Particle Size Analysis}

The hydrodynamic diameter of the dispersed particles in the liquid CM:PP blends and control samples were measured by dynamic light scattering using NanoBrook ZetaPALS Potential Analyzer (Brookhaven Instruments Corporation). We added $3 \mathrm{~mL}$ of distilled water to a clean cuvette, and then $100 \mu \mathrm{L}$ of liquid sample was added. Backscattering angle $173^{\circ}$ was used for weakly scattered particles such as proteins. The temperature was maintained at $25^{\circ} \mathrm{C}$ with an equilibration time of $1 \mathrm{~min}$. The measurements were performed over a range of 1.0 to $10,000 \mathrm{~nm}$ over $5 \mathrm{~min}$, and the sample specifications were set to be 0.133 refractive index, 0.890 $\mathrm{mPa} \cdot \mathrm{s}$ viscosity, and $\mathrm{pH}=7.0$. Results are reported as averages from 5 replicates.

\section{Soluble Protein Analysis}

The soluble protein content of each CM:PP blend and control sample were measured pre- and posthomogenization via Quick Start Bradford Protein Assay (Bio-Rad). We combined $20 \mu \mathrm{L}$ of 1:1,000 diluted sample with $140 \mu \mathrm{L}$ of Tris-HCl $50 \mathrm{mM}(\mathrm{pH}=8)$ buffer and $40 \mu \mathrm{L}$ of Bradford dye (Bio-Rad). The mix reaction was transferred to a 96 -well plate and mixed thor- 
oughly. The protein concentration was measured with a spectrophotometer (accuSkan GO 1510, Thermo Fisher Scientific) at a wavelength of $595 \mathrm{~nm}$. The standard curve was prepared using BSA (Bio-Rad).

\section{Compositional Analysis}

Moisture (\%), solids (\%), and fat (\%) of the CM:PP blends and homogenized milk and pea slurry controls were measured using manufacturer's instructions for Smart 6 CEM Milk 0T01-T6 method (CEM, Smart 6). The protein $(\%)$ of the CM:PP blends was measured via Dumas combustion using manufacturer's instructions on a Rapid MAX N-Exceed nitrogen and protein analyzer (Rapid MAX N-Exceed, Elementar). The conversion factor of 6.38 (milk) was used to convert elemental nitrogen to percent protein. The combined carbohydrates and ash (\%) were measured via difference in solids. Results are reported as averages from 3 replicates.

\section{Coagulation of CM:PP Blends}

We transferred $50 \mathrm{~mL}$ of each CM:PP blend to a clean test tube and placed in a $37^{\circ} \mathrm{C}$ incubator. Then, $1 \mathrm{~mL}$ of $\mathrm{CaCl}_{2} 1 \%$ was added to the sample and set for $10 \mathrm{~min}$ at $37^{\circ} \mathrm{C}$. To coagulate the $\mathrm{CN}$ in each blend, chymosin (Chy-Max M 127223, Chr. Hansen) was first diluted with distilled water to a 1:100 ratio, and $0.25 \mathrm{~mL}$ of this dilution was added to each sample and shaken gently back and forth for $30 \mathrm{~s}$. The samples were incubated at $37^{\circ} \mathrm{C}$ for $24 \mathrm{~h}$ to achieve full curd formation. Afterward, the curd was removed from the whey using a cheese cloth. Control experiments were carried out under the same conditions using homogenized skim milk (positive control) and homogenized PP slurry, which did not coagulate under these conditions (negative control). Each CM:PP blend was prepared in triplicate.

\section{SDS-PAGE}

To determine the profile of the proteins incorporated in the CM:PP blends (curd and whey components) compared with the control samples, 10\% SDS-PAGE gels were prepared in not-reducing conditions. A mixed solution containing the diluted sample with $45 \mu \mathrm{g}$ of protein and $2 \times$ Laemmli sample buffer $(65.8 \mathrm{~m} M$ Tris$\mathrm{HCl}, \mathrm{pH}$ 6.8, 2.1\% SDS, $26.3 \%$ glycerol, $0.01 \%$ bromophenol blue; Bio-Rad) was loaded into each well. The gel ran for $70 \mathrm{~min}$ at $120 \mathrm{~V}$. After the running time, the gels were stained with Coomassie blue (Bio-Rad), and an image of each gel was taken using Chemidoc-Touch Imaging System (Bio-Rad) and analyzed using Image Lab software 6.1 (Bio-Rad).

\section{3-Dimensional Laser Microscope}

An aliquot of each coagulated CM:PP blend was placed on a 3-mm microscope slide and gently dried at $37^{\circ} \mathrm{C}$ in an oven. Afterward, it was analyzed with a 3-dimensional laser microscope (VK-X200 series, Keyence) under different magnifications $(10 \times, 20 \times, 50 \times$, and $150 \times$ lenses). Four images were analyzed for each sample, and the most representative was chosen and depicted for analysis. Five areas of each image were analyzed to determine surface roughness $(\mathbf{S a}$; as the arithmetical mean height in $\mu \mathrm{m}$ ) using Multi File Analyzer software (version 1.3.1.120; Keyence). The averages of each CM:PP blend Sa values were compared with Sa values of the positive control (coagulated skim milk).

\section{Reversed-Phase HPLC}

The proteins of the CM:PP blends and control samples were separated and identified via reversedphase (RP)-HPLC (LC-20AD, Shimadzu USA Manufacturing Inc.) coupled to an Aeris 3.6- $\mu \mathrm{m}$ Widepore XB-C8 $(\mathrm{LC}$ column $250 \times 4.6 \mathrm{~mm}$ ) and a fluorescence detector (RF-10AXL, Shimadzu). Solvent A was $0.1 \%$ trifluoroacetic acid (TFA) in HPLC grade water and solvent B was $0.1 \%$ TFA in HPLC grade acetonitrile. Both solvents were degassed for 10 min before being vacuum filtered through a $0.22-\mu \mathrm{m}$ nylon filter. The flow rate was $1 \mathrm{~mL} / \mathrm{min}$. From 0 to $20 \mathrm{~min}$, solvent B was 25 to $50 \%$. From 20 to $30 \mathrm{~min}$, solvent B was 50 to $80 \%$. From 30 to $32 \mathrm{~min}$, solvent B was 80 to $25 \%$. The excitation wavelength $\left(\lambda^{\text {ex }}\right)$ and emission wavelength $\left(\lambda^{\mathrm{em}}\right)$ in the detector were 280 and $348 \mathrm{~nm}$, respectively, as these are the optimal wavelengths to detect tryptophan. The column oven was set at $40^{\circ} \mathrm{C}$, and the sample injection volume was $5 \mu \mathrm{L}$. The light emitted from the excited atoms from the analyte was measured in $\mu \mathrm{V}$. The samples were prepared by using the method described by Ma et al. (2017) with some modifications. In brief, $800 \mu \mathrm{L}$ of protein sample were combined with $800 \mu \mathrm{L}$ of solution A $(5.37 \mathrm{~m} M$ sodium citrate, 19.5 $\mathrm{m} M$ D-L-dithiothreitol, $6 \mathrm{M}$ guanidine hydrochloride in $0.1 M$ BisTris buffer, $\mathrm{pH}=7$ ). The samples were then vortexed for $10 \mathrm{~s}$ and incubated at room temperature for $1 \mathrm{~h}$. An aliquot of $500 \mu \mathrm{L}$ was further mixed with $1,000 \mu \mathrm{L}$ of solution B (4.5 M guanidine hydrochloride in a solution of water, acetonitrile, and TFA in a ratio 
of 89.9:10:0.1). The 1.5-mL sample mixture was filtered through a $0.22-\mu \mathrm{m}$ filter into an amber HPLC vial and stored at $4^{\circ} \mathrm{C}$ until the day of analysis.

\section{AA Sequencing}

The AA sequence of the PP of interest was analyzed via capillary-liquid chromatography-nanospray tandem mass spectrometry (LC/MS/MS). The protein sample was loaded into a $10 \%$ SDS-PAGE stained in Coomassie blue. The single band was excised from the gel and was analyzed at The Mass Spectrometry and Proteomics Facility (Ohio State University, Columbus). They performed an in-gel digestion with sequencing grade-modified trypsin and extracted the peptides. The peptides were separated via capillary-LC/MS/MS and the data collected was searched in Mascot Daemon by Matrix Science version 2.7.0. Proteins identified with at least 2 unique peptides were considered to be a reliable identification.

\section{Statistical Analysis}

All experiments were conducted in quintet (particle size analysis, Sa) or triplicate (compositional analysis, soluble protein). One-way ANOVA analyses followed by Tukey-Kramer HSD multiple-comparison were conducted to determine statistical differences $(P<0.05)$ between pairs using JMP software (JMP 14.0.0, SAS Institute Inc.).

\section{RESULTS AND DISCUSSION}

\section{Disruption of CM}

Successful encapsulations within CM first involve the disruption of the micelle to expose the hydrophobic core to facilitate greater interactions with the added hydrophobic compound (Głąb and Boratyński, 2017). The proposed protocol suggests using a temperature decrease and an addition of sodium citrate to disrupt the CM structure. For the purpose of the study, it was assumed that the soluble particles in milk were all CM, due to the low percentage and small size of serum proteins, in addition to the low percentage of fat present (Holt, 1985; Beliciu and Moraru, 2009). We observed significantly larger sized $\mathrm{CM}$ in the $4^{\circ} \mathrm{C}$ milk compared with the $60^{\circ} \mathrm{C}$ milk, with hydrodynamic diameters $($ mean $\pm \mathrm{SD}$ ) of $197.11 \pm 2.07 \mathrm{~nm}$ and $163.15 \pm 5.28$ $\mathrm{nm}$, respectively $(P<0.0001$; data not shown). Upon the addition of sodium citrate to the milk at $4^{\circ} \mathrm{C}$, the hydrodynamic diameter increased to $220.06 \pm 2.34 \mathrm{~nm}$, which was significantly greater than the milk with no sodium citrate addition $(P<0.0001$; data not shown). In addition to the larger soluble particle size, the milk at $4^{\circ} \mathrm{C}+$ sodium citrate appeared less turbid and less white, indicating a successful disruption of the micelle structure (Fox et al., 2015). These results support the proposed protocol to use low-temperature $\left(4^{\circ} \mathrm{C}\right)$ processing methods in combination with sodium citrate addition to successfully disrupt the CM structure.

\section{Soluble Protein Analysis}

Three CM:PP blends at different ratios pre- and posthomogenization are shown in Figure 1A. The prehomogenized blends at all CM:PP ratios showed clear separation between the 2 protein segments, an indication of an unstable colloidal dispersion. The insoluble PP settled out of solution and formed a solid pellet. On the other hand, the posthomogenized blends at all CM:PP ratios were homogeneous with no visible sedimentation. All 3 posthomogenized blends remained visibly stable at $4^{\circ} \mathrm{C}$ for up to $3 \mathrm{wk}$ with no formation of an insoluble pellet. The soluble protein content (Figure 1B) of the 90:10 and 50:50 blends significantly increased upon homogenization $(90: 10, P=0.0268 ; 50: 50, P$ $=0.0015)$. The soluble protein content of the 80:20 blend also increased upon homogenization, but not by a significant value $(80: 20 P=0.0924)$. The process of homogenization has been shown to disrupt the 3-dimensional globular PP bodies into smaller, more soluble aggregates suspended in the aqueous phase (Moll et al., 2021). In agreement with Moll et al. (2021), the present results supported the disruption of globular PP bodies by the fact that the PP slurry control prehomogenization had a soluble protein content of $8.24 \pm 1.38 \mathrm{mg} /$ $\mathrm{mL}$, which significantly increased posthomogenization to $66.47 \pm 17.06 \mathrm{mg} / \mathrm{mL}(P=0.0041$; Figure $1 \mathrm{~B})$.

\section{Compositional Analysis}

The compositional analysis of the 90:10, 80:20, and 50:50 CM:PP blends were compared with commercial skim milk in Table 1. As expected, the 90:10 CM:PP blend had the most similar composition to skim milk. There was no significant difference between the 90:10 CM:PP blend and skim milk moisture content $(P=$ $0.3397)$, solids content $(P=0.3366)$, and protein content $(P=1.0)$. In general, as the amount of $\mathrm{PP}$ in the blend increased, the moisture content increased, and the solids content decreased. This result was expected because the initial PP slurry only had a solids content of $3.3 \%$, compared with the initial skim milk with a solids content of $9.05 \%$, due to the additional components in milk. As the PP content of the blend 
A

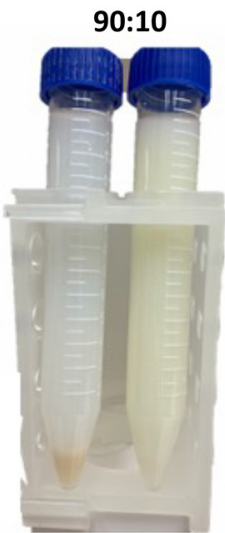

Pre- Post-
Ratio

CM:PP

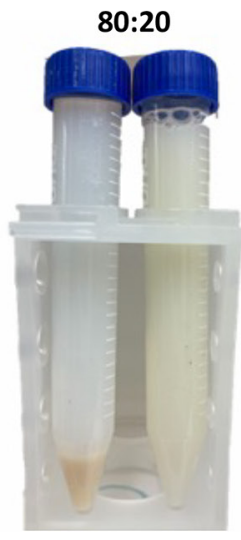

Pre- Post-
B

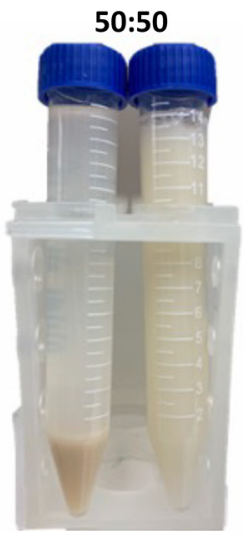

Pre- Post-
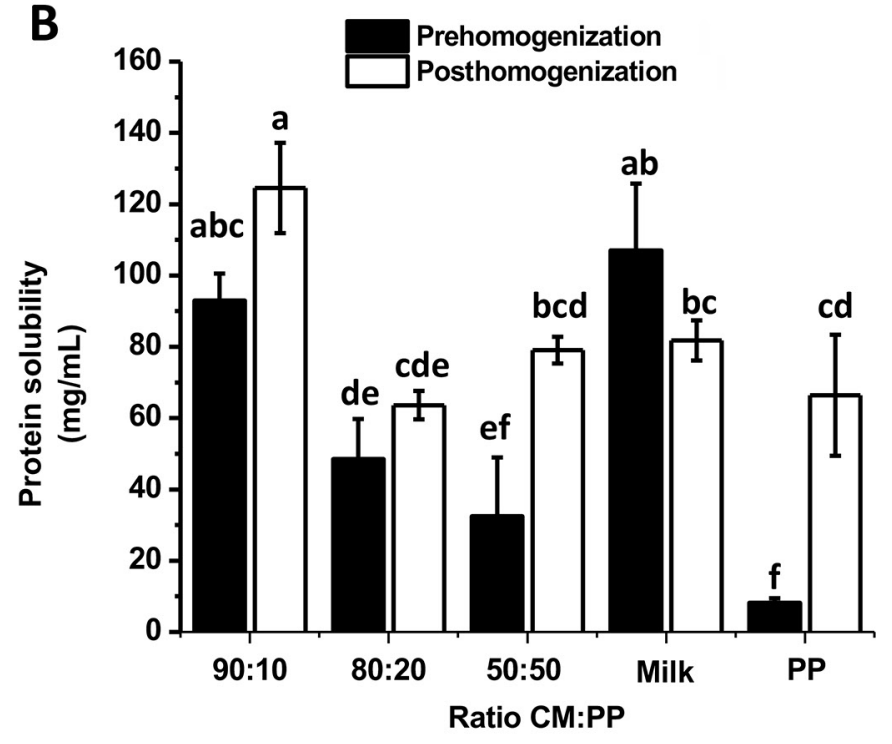

Homogenization

Figure 1. (A) Casein micelle:pea protein (CM:PP) blends pre- and posthomogenization. (B) Soluble protein (mg/mL) of CM:PP blends and controls, pre- and posthomogenization. Values are means of data from triplicate experiments with standard deviation indicated by vertical bars. Different lowercase letters $(\mathrm{a}-\mathrm{f})$ indicate a significant difference $(P<0.05)$.

increased, the protein content significantly decreased compared with skim milk. The 80:20 and 50:50 CM:PP blends had statistically similar protein contents to each other $(P=0.6088)$, but statistically different protein contents to the 90:10 CM:PP blend $(P=0.0231$ and $P=0.0045$, respectively $)$ and skim milk $(P=0.0246$ and $P=0.0048$, respectively). Protein content in milk is affected by the genetics, age, stage of lactation, and nutrition of the cow and is not standardized in the industry (Linn, 1988). In the case of this study, the skim milk protein content was $4.72 \pm 0.03 \%$, which was greater than what was expected based on the nutritional label (3.3\%). Therefore, the protein content inevitably decreased upon the replacement of skim milk with PP slurry in the blend. All CM:PP blends and skim milk have statistically similar fat contents $(P=$ $0.1348)$. There was relatively little fat to begin with in the skim milk $(0.07 \%)$, and the PP contributed negligible fat to the blend.

\section{Particle Size Analysis}

We measured the hydrodynamic diameter of the dispersed particles in pre- and posthomogenized skim milk and PP slurry controls to understand the effect of low-temperature processing on the individual protein components. The particle size of $\mathrm{CM}$ in skim milk did not change significantly between pre-homogenization and posthomogenization $(220.06 \pm 2.34$ $\mathrm{nm}$ and $216.00 \pm 8.35 \mathrm{~nm}$, respectively; $P=0.8721$; Figure 2). This result was expected because the size and structure of $\mathrm{CM}$ is not affected at pressures less than $200 \mathrm{MPa}$ (Huppertz et al., 2004, 2006). On the other hand, the soluble particle size of PP slurry prehomogenization was significantly greater than the PP slurry posthomogenization $(956.80 \pm 10.30 \mathrm{~nm}$ and $323.18 \pm 5.85 \mathrm{~nm}$, respectively; $P<0.0001$; Figure 2 ). Smaller protein aggregates tend to have improved solubility due to the increased surface area and elec-

Table 1. Compositional data (mean $\pm \mathrm{SD})$ of $\mathrm{CM}: \mathrm{PP}^{1}$ blends and skim milk

\begin{tabular}{lccccc}
\hline Sample (CM:PP) & Moisture (\%) & Solids (\%) & Protein $(\%)$ & Fat $(\%)$ & CHO $+\operatorname{ash}^{2}(\%)$ \\
\hline $90: 10$ & $91.31 \pm 0.01^{\mathrm{c}}$ & $8.69 \pm 0.01^{\mathrm{a}}$ & $4.73 \pm 0.07^{\mathrm{a}}$ & $0.09 \pm 0.02^{\mathrm{a}}$ & 4.82 \\
$80: 20$ & $92.00 \pm 0.08^{\mathrm{b}}$ & $7.99 \pm 0.06^{\mathrm{b}}$ & $4.29 \pm 0.10^{\mathrm{b}}$ & $0.08 \pm 0.01^{\mathrm{a}}$ & 4.36 \\
$50: 50$ & $94.31 \pm 0.47^{\mathrm{a}}$ & $5.69 \pm 0.47^{\mathrm{c}}$ & $4.14 \pm 0.25^{\mathrm{b}}$ & $0.10 \pm 0.01^{\mathrm{a}}$ & 4.24 \\
Skim milk & $90.95 \pm 0.10^{\mathrm{c}}$ & $9.05 \pm 0.10^{\mathrm{a}}$ & $4.72 \pm 0.03^{\mathrm{a}}$ & $0.07 \pm 0.02^{\mathrm{a}}$ & 4.57 \\
\hline
\end{tabular}

\footnotetext{
${ }^{\mathrm{a}-\mathrm{c}}$ Different lowercase letters indicate a significant difference $(P<0.05)$.

${ }^{1} \mathrm{CM}: \mathrm{PP}=$ ratio of casein micelle to pea protein.

${ }^{2} \mathrm{By}$ difference; $\mathrm{CHO}=$ carbohydrates.
} 
trostatic forces between protein and water molecules (Jambrak et al., 2008; Jiang et al., 2017). This improved solubility correlated to the increased soluble protein and smaller dispersed particle sizes identified in the PP slurry posthomogenization. Based on the hydrodynamic diameter results, it was inferred that any change in soluble particle size in the blends was due to the disruption of globular PP.

The hydrodynamic diameter of each CM:PP blend was analyzed pre- and posthomogenization (Figure 2). The soluble particle size of the 80:20 and 50:50 blends increased significantly posthomogenization $(P=0.0006$ and $P<0.0001$, respectively). Before homogenization, $\mathrm{CM}$ were the major soluble particle represented in the blend. However, after homogenization, insoluble globular PP were disrupted into smaller soluble aggregates that contributed to the increase in soluble particle size and content. However, these results do not show how the PP interact in the soluble phase or whether or not they associate with any milk component. On the other hand, the soluble particle size of the 90:10 blend decreased upon homogenization. The authors believe that the PP was not in sufficient quantity (10\%) to have a significant effect on increasing the overall soluble particle size or that the 90:10 ratio created smaller complexes of casein and PP (Figure 2).

\section{Protein Profile Analysis}

Sodium dodecyl sulfate-PAGE analysis was used to understand qualitatively how the PP incorporate within the soluble phase. We analyzed homogenized skim milk and PP slurry via SDS-PAGE (Figure 3). The major milk proteins included immunoglobulins, lactoferrin, BSA, CN, $\beta-\mathrm{LG}$, and $\alpha$-LA, which have molecular weights of $160,80,66.5,20$ to $25,18.3$, and $14.2 \mathrm{kDa}$, respectively (El-Loly, 2007; Edwards and Jameson, 2014; Vincent et al., 2016). About $80 \%$ of PP represents the following insoluble storage globulin proteins: legumin, vicilin, and convicilin (Barac et al., 2010). Legumin contains various subunits of $40-$ and $20-\mathrm{kDa}$ molecular weights. Vicilin is composed of subunits with molecular weights of $\sim 50, \sim 47, \sim 34$, and $\sim 30 \mathrm{kDa}$ subunits. Convicilin contains subunits of $\sim 71 \mathrm{kDa}$ (Barac et al., 2010). Figure 3 shows an intense band around $47 \mathrm{kDa}$ in the PP slurry (lane 1); however, there is no band in the skim milk (lane 2) at this similar molecular weight. This $\mathrm{PP}$ at $47 \mathrm{kDa}$ is easily identifiable and will not be confused with any milk proteins, and thus can be used as an indicator to determine where the PP incorporates within the blend (whey proteins, CM, or self-association). To assess what fraction was enriched in PP, the CM:PP blends and controls were coagulated with rennin Chy-Max M 127223 to separate the whey proteins (soluble fraction) from CM (coagulated precipitate). The CM:PP blends and milk coagulated under these conditions; however, the PP slurry did not. We analyzed the total uncoagulated blend, the liquid whey component, and the solid CN curd component through SDS-PAGE (Figure 4).

All CM:PP blends contained the $47 \mathrm{kDa}$ band (Figure 4 lanes 1,4, and 7), which remained in all the CM fractions (Figure 4 lanes 3,6 and 9) rather than the whey fractions (Figure 4 lanes 2, 5, and 8), indicating that the homogenization process incorporated this PP into CM. To identify the $47-\mathrm{kDa}$ protein, we conducted AA sequence analysis. We identified 44 peptides that represented $77 \%$ of coverage with a pea vicilin sequence using the NCBI BLAST database (https:/ /blast.ncbi.nlm.nih.gov/Blast.cgi; data not shown). These observations confirmed the incorporation of the insoluble storage globulin PP vicilin with CM via lowtemperature homogenization. The method limitation of SDS-PAGE as applied to this experiment was the inability to differentiate PP from milk proteins through characteristics other than molecular weight. For this reason, only the $47 \mathrm{kDa}$ vicilin was identified as incorporating within the $\mathrm{CM}$; however, it is possible that other PP also incorporate within the CM. Additional methods such as electron microscopy that can better

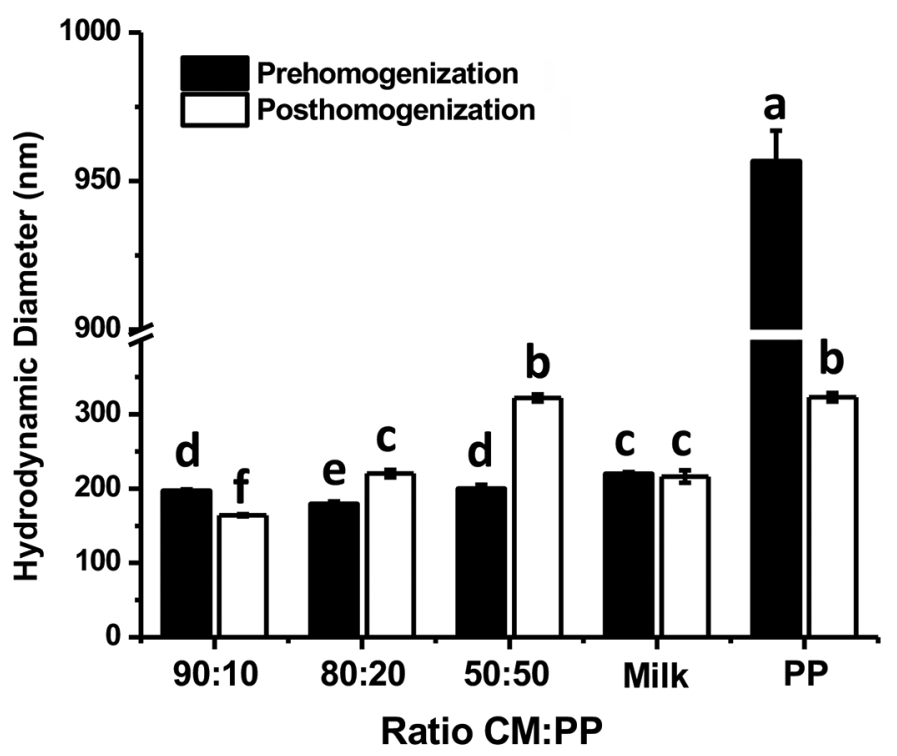

Figure 2. Hydrodynamic diameter ( $\mathrm{nm}$ ) of dispersed particles of casein micelle:pea protein (CM:PP) blends and controls, pre- and posthomogenization. Values are means of data from triplicate experiments with standard deviation indicated by vertical bars. Different lowercase letters $(\mathrm{a}-\mathrm{f})$ indicate a significant difference $(P<0.05)$. 


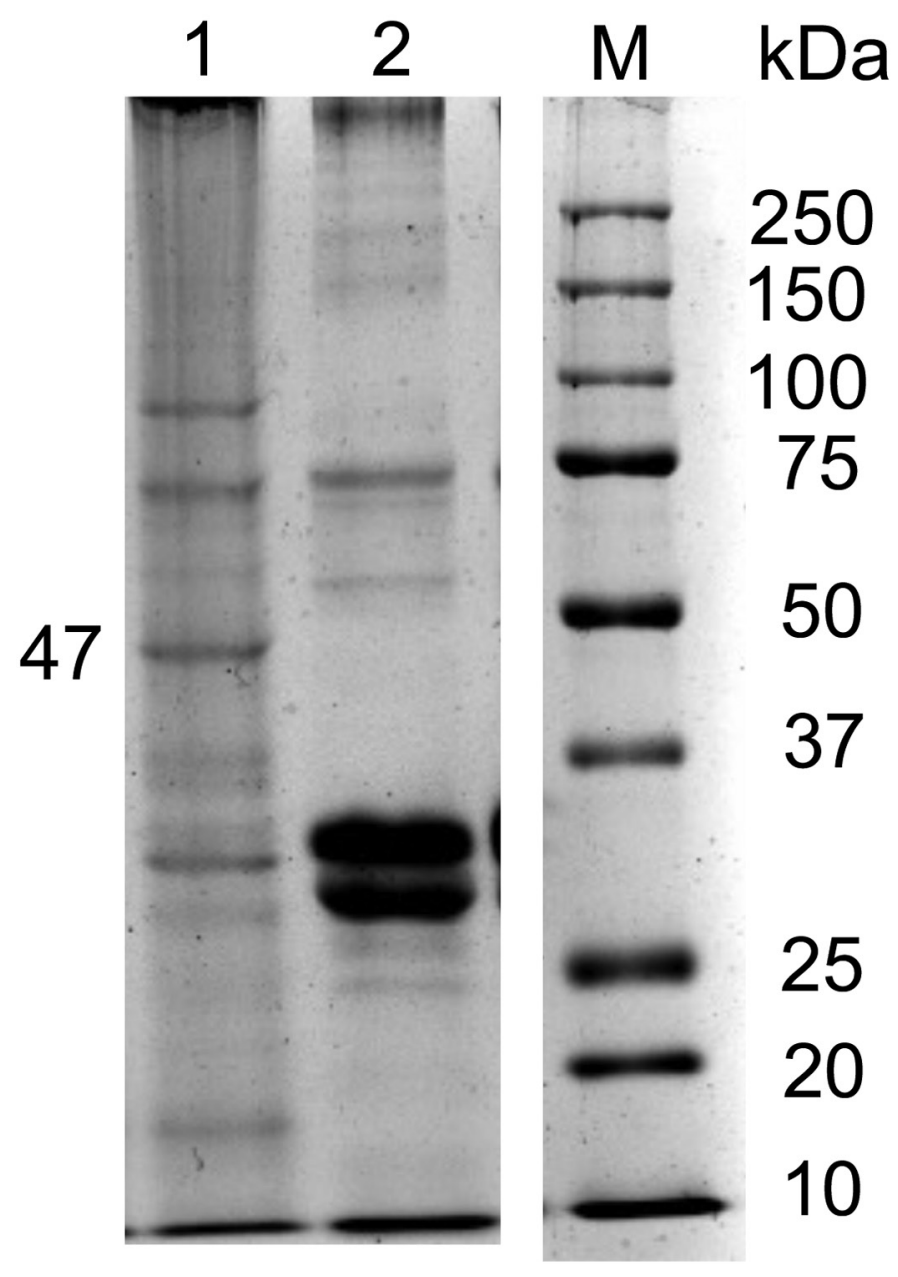

Figure 3. Sodium dodecyl sulfate-PAGE (10\%) stained in Coomassie blue of homogenized pea protein (lane 1) and skim milk (lane 2). Forty-five micrograms of protein was loaded in each well. $\mathrm{M}=$ the molecular weight marker (Precision Plus Protein All Blue, Bio-Rad).

differentiate between PP and CM may be used in future experiments (Jiang et al., 2017).

\section{RP-HPLC Analysis}

We used RP-HPLC with fluorescence detection to further understand the interaction between PP and CM in the blend based on their intrinsic protein fluorescence due to aromatic side chains such as Trp, Tyr, and Phe (Lu et al., 2020). Figure 5 shows the chromatogram of the CM:PP blends and their respective whey components after coagulation compared with skim milk and PP slurry. There were 2 fluorescence peaks produced by $\mathrm{PP}$ at 6.7 and $12.8 \mathrm{~min}$, whereas skim milk did not have a signal at these retention times, indicating that $\mathrm{PP}$ was the cause of this fluorescence. In contrast, the $\mathrm{PP}$ fluorescence was detected in all $3 \mathrm{CM}: \mathrm{PP}$ blends at these specific retention times, but not in their whey components, indicating again that $\mathrm{PP}$ were interacting with the CM. The results from RP-HPLC further demonstrated that the proposed protocol described in this paper effectively created a stable colloidal dispersion between insoluble PP and CM. It should be noted that the RP-HPLC analysis was only used for qualitative results due to the lack of available commercial standards for pea vicilin.

\section{Microstructure Analysis}

The surface of the curd component of the CM:PP blends was further analyzed by 3-dimensional laser microscopy. Figure 6 shows the 90:10, 80:20, and 50:50 CM:PP curds under $150 \times$ lens compared with a skim milk curd. Through visual comparison, the skim milk curd had fewer, but more pronounced, CN coagulates on the curd surface. As the amount of PP increased, the size of the surface ridges decreased, and the ridges became more numerous. The 90:10 curd had very pronounced surface ridges in the lower part of the image that were similar to the milk CN coagulate. However, in the upper right area of the 90:10 curd surface, the texture started to look more similar to the 80:20 curd surface. The 50:50 curd surface looked different than the skim milk curd, with unrecognizable coagulates compared with the intact $\mathrm{CN}$ coagulates. The 50:50 curd had less pronounced ridges, but they were more numerous. The arithmetical mean height was measured to evaluate the Sa. As the amount of PP increased, the surface roughness $(\mu \mathrm{m})$ decreased. The ranking of the surface roughness of each sample was as follows: skim milk $(3.99 \pm 2.63 \mu \mathrm{m})>90: 10$ blend $(2.70 \pm 1.70 \mu \mathrm{m})$ $>80: 20$ blend $(1.70 \pm 0.58 \mu \mathrm{m})>50: 50$ blend $(0.79 \pm$ $0.38 \mu \mathrm{m})$. The surface roughness of the skim milk was significantly different than the surface roughness of the 80:20 CM:PP blend $(P=0.0002)$ and the 50:50 CM:PP blend $(P<0.0001)$. We hypothesized that this change in surface texture was due to the incorporation of PP in the $\mathrm{CN}$ structure, which disrupted the $\mathrm{CN}$ coagulum.

\section{CONCLUSIONS}

In this work, we were able to take advantage of the conformational changes that CM undergo upon exposure to cold temperatures and sodium citrate addition to prepare a codispersion with PP that significantly increased the stability of this hydrophobic protein fraction in colloidal suspensions. Our method to create a stable colloidal dispersion used the unique CM structure optimal for protein blending and current dairy processing equipment, such as homogenizers, to allow for easy reproducibility in any dairy facility. The CM:PP blend showed promising results for the use of mixed protein, 


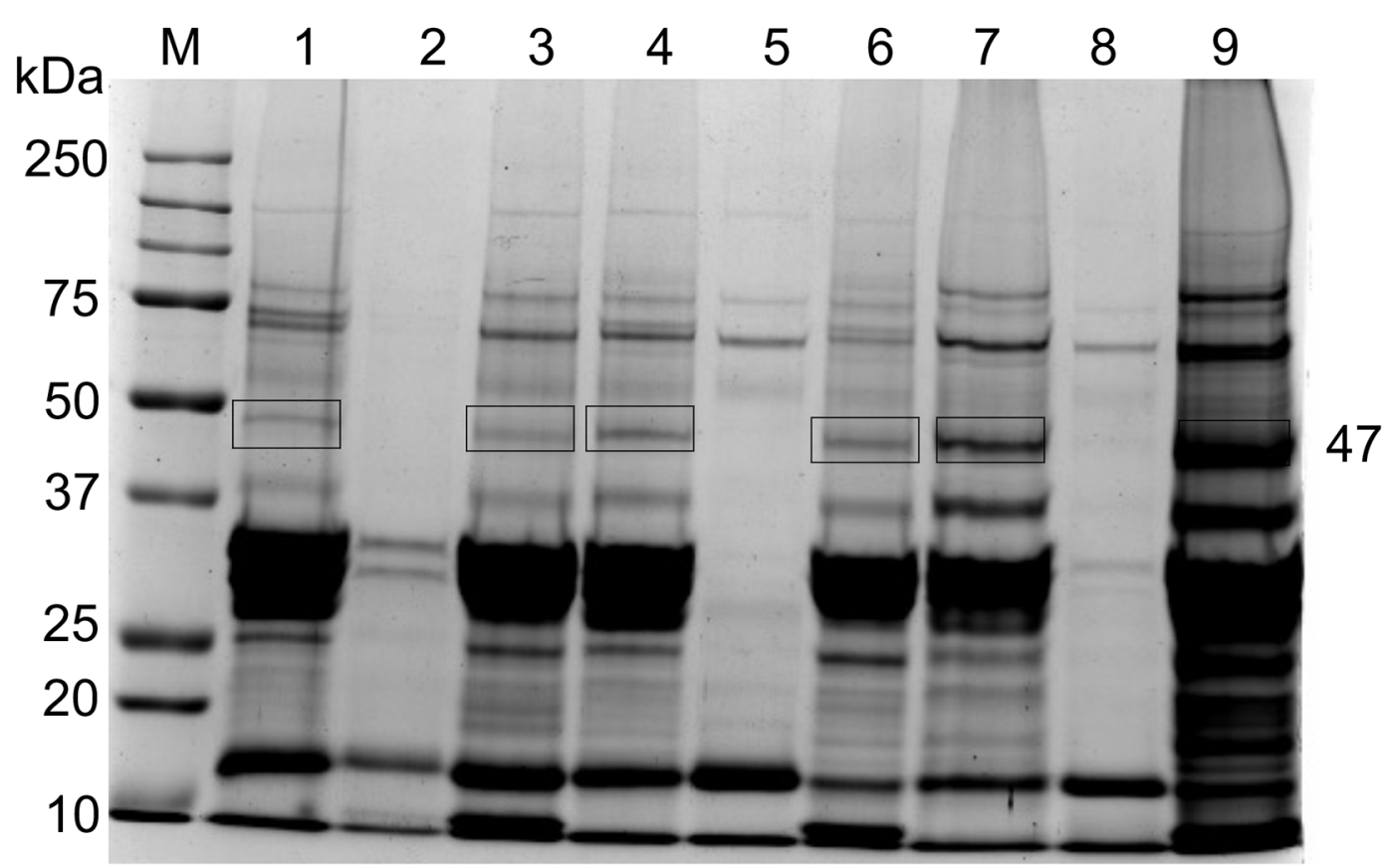

Figure 4. Sodium dodecyl sulfate-PAGE (10\%) stained in Coomassie blue of casein micelle:pea protein (CM:PP) blends (90:10, 80:20, 50:50) and their respective whey and $\mathrm{CN}$ components. $\mathrm{M}=$ molecular weight marker; lane $1=90: 10$ total blend; lane $2=90: 10$ whey component; lane $3=90: 10 \mathrm{CN}$ component; lane $4=80: 20$ total blend; lane $5=80: 20$ whey component; lane $6=80: 20 \mathrm{CN}$ component; lane $7=50: 50$ total blend; lane $8=50: 50$ whey component; lane $9=50: 50 \mathrm{CN}$ component. Forty-five micrograms of protein was loaded in each well.

functional food product in the form of liquid, gel, or powder applications. Future experiments should deal with the amount of PP that associates within the CM, the nature of these associations, and sensory analysis. There is great potential to apply this research to other plant-based proteins or nutraceuticals with low solubil-

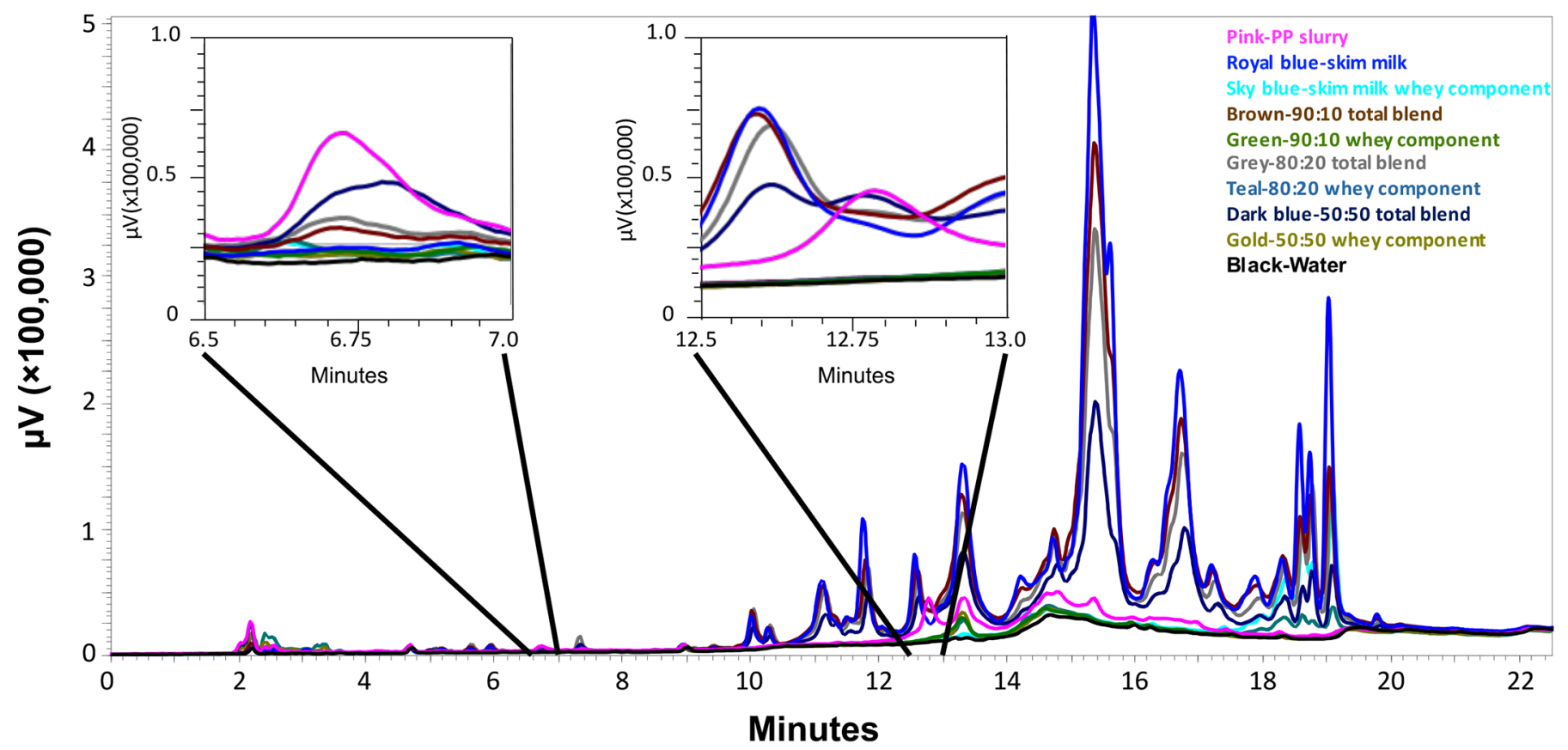

Figure 5. Reversed-phase HPLC with fluorescence detection chromatogram of casein micelle:pea protein (CM:PP) blends and their respective whey components compared with skim milk and homogenized PP slurry. 


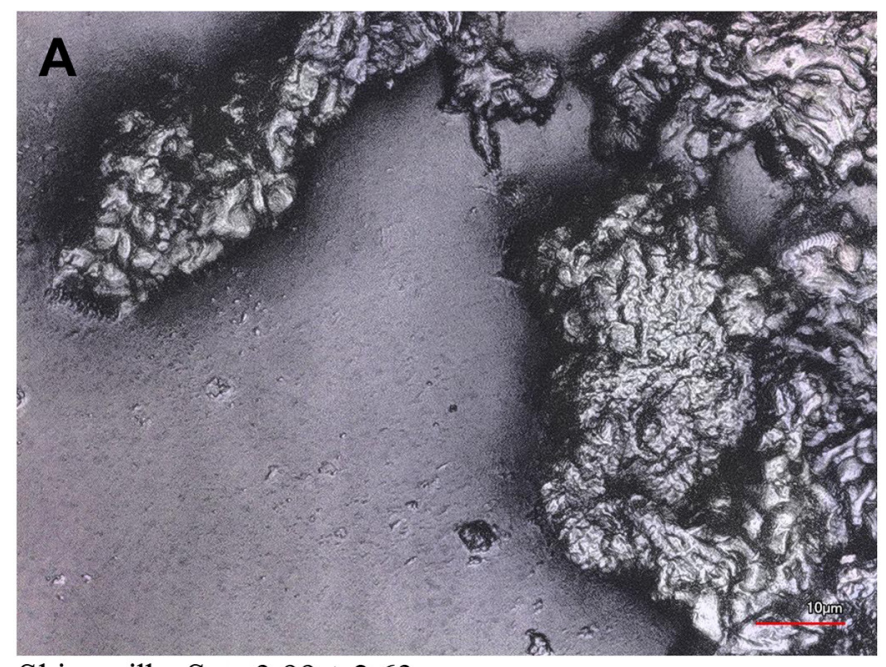

Skim milk: $\mathrm{Sa}=3.99 \pm 2.63 \mu \mathrm{m}$

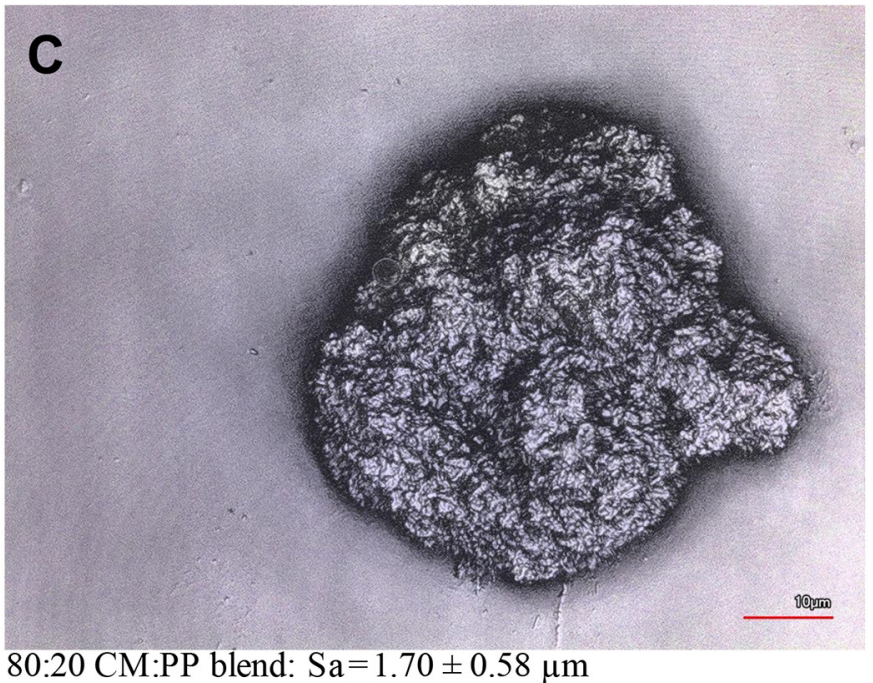

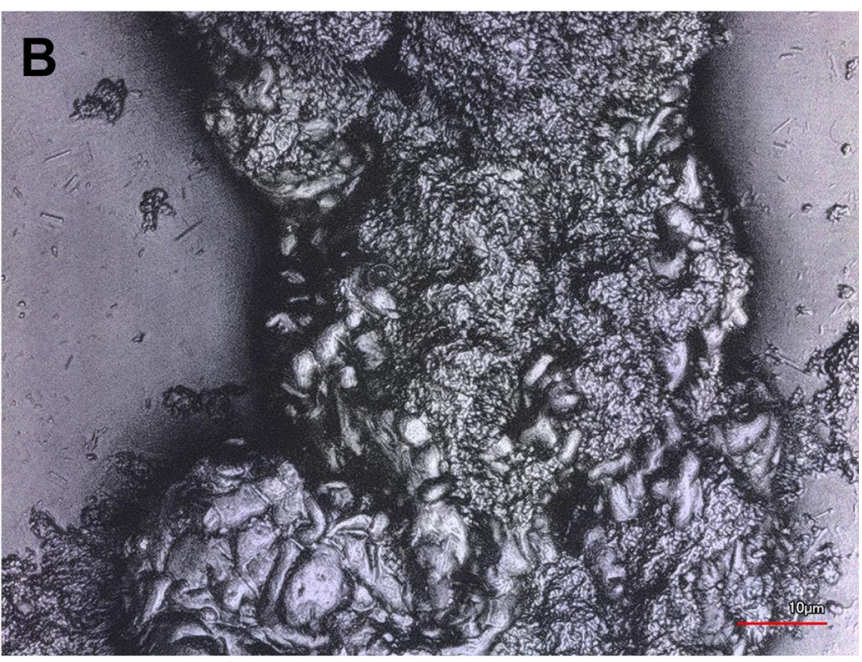

90:10 CM:PP blend: $\mathrm{Sa}=2.70 \pm 1.70 \mu \mathrm{m}$

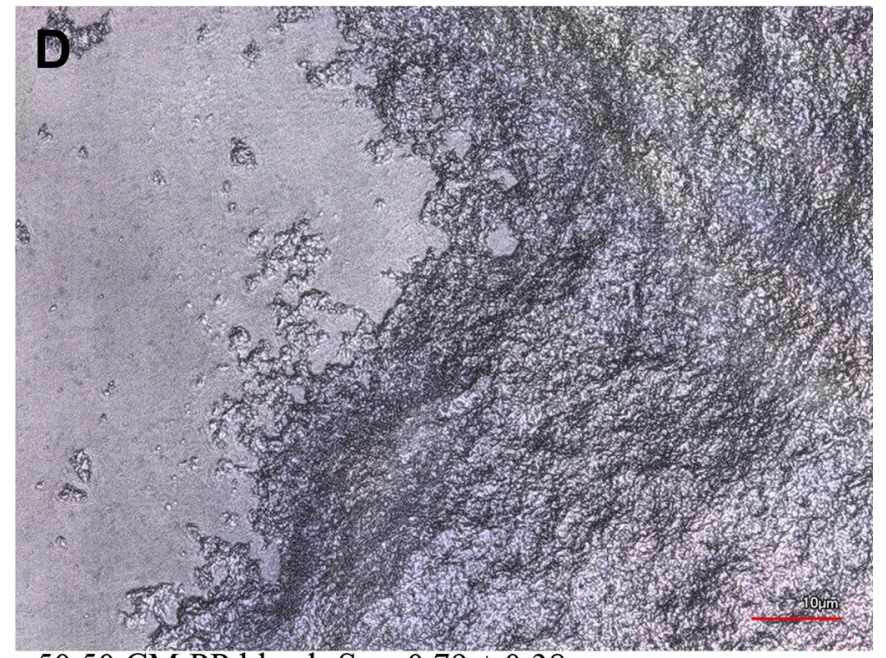

50:50 CM:PP blend: $\mathrm{Sa}=0.79 \pm 0.38 \mu \mathrm{m}$

Figure 6. Three-dimensional laser micrographs of (A) coagulated skim milk, (B) 90:10 casein micelle:pea protein (CM:PP) blend, (C) 80:20 CM:PP blend, and (D) 50:50 CM:PP blend. Red scale $=10 \mu \mathrm{m}$. Sa $=$ surface roughness (mean $\pm \mathrm{SD}$ ).

ity to be further used in an innovative way that allows the dairy industry to provide highly nutritious protein products, while also capitalizing on current consumer trends.

\section{ACKNOWLEDGMENTS}

This project was funded by the Parker Endowment (Department of Food Science and Technology, The Ohio State University, Columbus). The project was supported by NIH (Bethesda, MD) award number grant P30 CA016058 for the use of the CCIC Mass Spectrometry and Proteomics (MSandP) Facility (Columbus, $\mathrm{OH}$ ) services and resources. The Fusion Orbitrap instrument was supported by NIH award number grant S10 OD018056. The authors thank Molly Davis
(Department of Food Science and Technology, The Ohio State University, Columbus) for her editing. The authors have not stated any conflicts of interest.

\section{REFERENCES}

Babault, N., C. Païzis, G. Deley, L. Guérin-Deremaux, M.-H. Saniez, C. Lefranc-Millot, and F. A. Allaert. 2015. Pea proteins oral supplementation promotes muscle thickness gains during resistance training: A double-blind, randomized, placebo-controlled clinical trial vs. whey protein. J. Int. Soc. Sports Nutr. 12:3. https://doi .org/10.1186/s12970-014-0064-5.

Barac, M., S. Cabrilo, M. Pesic, S. Stanojevic, S. Zilic, O. Macej, and N. Ristic. 2010. Profile and functional properties of seed proteins from six pea (Pisum sativum). Int. J. Mol. Sci. 11:4973-4990. https://doi.org/10.3390/ijms11124973.

Beliciu, C. M., and C. I. Moraru. 2009. Effect of solvent and temperature on the size distribution of casein micelles measured by 
dynamic light scattering. J. Dairy Sci. 92:1829-1839. https://doi .org/10.3168/jds.2008-1467.

Boland, M. J., A. N. Rae, J. M. Vereijken, M. P. M. Meuwissen, A. R. H. Fischer, M. A. J. S. van Boekel, S. M. Rutherfurd, H. Gruppen, P. J. Moughan, and W. H. Hendriks. 2013. The future supply of animal-derived protein for human consumption. Trends Food Sci. Technol. 29:62-73. https://doi.org/10.1016/j.tifs.2012.07.002.

Cohen, Y., S. Ish-Shalom, E. Segal, O. Nudelman, A. Shpigelman, and Y. D. Livney. 2017. The bioavailability of vitamin $\mathrm{D}_{3}$, a model hydrophobic nutraceutical, in casein micelles, as model protein nanoparticles: Human clinical trial results. J. Funct. Foods 30:321325. https://doi.org/10.1016/j.jff.2017.01.019

Edwards, P. J. B., and G. B. Jameson. 2014. Chapter 7-Structure and stability of whey proteins. Pages 201-242 in Milk Proteins, Second Edition. H. Singh, M. Boland, and A. Thompson, ed. Academic Press.

El-Loly, M. M. 2007. Bovine milk immunoglobulins in relation to human health. Int. J. Dairy Sci. 2:183-195. https://doi.org/10.3923/ ijds.2007.183.195.

Fox, P. F., T. Uniacke-Lowe, P. L. H. McSweeney, and J. A. O'Mahony. 2015. Pages 145-241 in Dairy chemistry and biochemistry. Springer International Publishing.

Ghasemi, S., and S. Abbasi. 2014. Formation of natural casein micelle nanocapsule by means of $\mathrm{pH}$ changes and ultrasound. Food Hydrocoll. 42:42-47. https://doi.org/10.1016/j.foodhyd.2013.10.028.

Głąb, T. K., and J. Boratyński. 2017. Potential of casein as a carrier for biologically active agents. Top. Curr. Chem. (Cham) 375:71. https://doi.org/10.1007/s41061-017-0158-z.

Heertje, I., J. Visser, and P. Smits. 1985. Structure formation in acid milk gels. Food Structure 4:10.

Holt, C. 1985. The size distribution of bovine casein micelles: A review. Food Structure 4:2.

Holt, C., and D. S. Horne. 1996. The hairy casein micelle: Evolution of the concept and its implications for dairy technology. Neth. Milk Dairy J. 50:1-27.

Horne, D. S. 1998. Casein interactions: Casting light on the black boxes, the structure in dairy products. Int. Dairy J. 8:171-177. https://doi.org/10.1016/S0958-6946(98)00040-5.

Huppertz, T., P. F. Fox, K. G. de Kruif, and A. L. Kelly. 2006. High pressure-induced changes in bovine milk proteins: A review. Biochim. Biophys. Acta. 1764:593-598. https://doi.org/10.1016/j .bbapap.2005.11.010

Huppertz, T., P. F. Fox, and A. L. Kelly. 2004. High pressure treatment of bovine milk: Effects on casein micelles and whey proteins. J. Dairy Res. 71:97-106. https://doi.org/10.1017/ S002202990300640X.

Jambrak, A. R., T. J. Mason, V. Lelas, Z. Herceg, and I. L. Herceg. 2008. Effect of ultrasound treatment on solubility and foaming properties of whey protein suspensions. J. Food Eng. 86:281-287. https://doi.org/10.1016/j.jfoodeng.2007.10.004.
Jiang, S., J. Ding, J. Andrade, T. M. Rababah, A. Almajwal, M. M. Abulmeaty, and H. Feng. 2017. Modifying the physicochemical properties of pea protein by $\mathrm{pH}$-shifting and ultrasound combined treatments. Ultrason. Sonochem. 38:835-842. https://doi.org/10 .1016/j.ultsonch.2017.03.046.

Koutina, G., J. C. Knudsen, U. Andersen, and L. H. Skibsted. 2014 Temperature effect on calcium and phosphorus equilibria in relation to gel formation during acidification of skim milk. Int. Dairy J. 36:65-73. https://doi.org/10.1016/j.idairyj.2014.01.003.

Linn, J. G. 1988. Factors affecting the composition of milk from dairy cows. Pages 224-238 in Designing Foods: Animal Product Options in the Marketplace. National Academies Press (US).

Liu, D. Z., M. G. Weeks, D. E. Dunstan, and G. J. O. Martin. 2013. Temperature-dependent dynamics of bovine casein micelles in the range $10-40^{\circ} \mathrm{C}$. Food Chem. 141:4081-4086. https://doi.org/10 .1016/j.foodchem.2013.06.130.

Lu, Z. X., J. F. He, Y. C. Zhang, and D. J. Bing. 2020. Composition, physicochemical properties of pea protein and its application in functional foods. Crit. Rev. Food Sci. Nutr. 60:2593-2605. https:/ /doi.org/10.1080/10408398.2019.1651248.

Ma, L., Y. Yang, J. Chen, J. Wang, and D. Bu. 2017. A rapid analytical method of major milk proteins by reversed-phase high-performance liquid chromatography. Anim. Sci. J. 88:1623-1628. https:/ /doi.org/10.1111/asj.12804.

Menéndez-Aguirre, O., A. Kessler, W. Stuetz, T. Grune, J. Weiss, and J. Hinrichs. 2014. Increased loading of vitamin $\mathrm{D}_{2}$ in reassembled casein micelles with temperature-modulated high-pressure treatment. Food Res. Int. 64:74-80. https://doi.org/10.1016/j.foodres .2014.06.010.

Menéndez-Aguirre, O., W. Stuetz, T. Grune, A. Kessler, J. Weiss, and J. Hinrichs. 2011. High pressure-assisted encapsulation of vitamin $\mathrm{D}_{2}$ in reassembled casein micelles. High Press. Res. 31:265-274. https://doi.org/10.1080/08957959.2011.565057.

Moll, P., H. Salminen, C. Schmitt, and J. Weiss. 2021. Impact of microfluidization on colloidal properties of insoluble pea protein fractions. Eur. Food Res. Technol. 247:545-554. https://doi.org/ 10.1007/s00217-020-03629-2.

Nehete, J. Y., R. S. Bhambar, M. R. Narkhede, and S. R. Gawali. 2013. Natural proteins: Sources, isolation, characterization and applications. Pharmacogn. Rev. 7:107-116. https://doi.org/10.4103/ 0973-7847.120508.

Pierre, A., and G. Brule. 1981. Mineral and protein equilibria between the colloidal and soluble phases of milk at low temperature. J. Dairy Res. 48:417-428. https://doi.org/10.1017/S0022029900021890.

Vincent, D., A. Elkins, M. R. Condina, V. Ezernieks, and S. Rochfort. 2016. Quantitation and identification of intact major milk proteins for high-throughput LC-ESI-Q-TOF MS analyses. PLoS One 11:e0163471. https://doi.org/10.1371/journal.pone.0163471.

Walstra, P. 1999. Casein sub-micelles: Do they exist? Int. Dairy J. 9:189-192. https://doi.org/10.1016/S0958-6946(99)00059-X. 